\title{
The dynamics of community response to the development of the New Capital (IKN) of Indonesia
}

\author{
A. Kodir*, N. Hadi, I.K. Astina, D. Taryana, N. Ratnawati \& Idris \\ Universitas Negeri Malang, Malang, Indonesia
}

\begin{abstract}
This research focuses on mapping the responses of the actors involved in the development plan for the New Capital (IKN) of Indonesia in East Kalimantan. The research method used is descriptive-qualitative with the main data source through in-depth interviews with several key informers and supporting informants. The results showed that there were three forms of response dynamics to the development of IKN in East Kalimantan. 1) Those who accept the construction of the IKN, this group are optimistic that the existence of the IKN will bring about socio-economic changes in the community for the better. 2) Most of the parties who reject the IKN development consist of indigenous peoples and several NGOs in East Kalimantan. The reasons for rejection were the concern about the land of indigenous peoples in the construction site. 3) Moderate or middle-class parties: this party views the IKN development from two sides.
\end{abstract}

Keywords: Capital, Development, Dynamics, Indonesia, Response.

\section{INTRODUCTION}

DKI Jakarta Province, which is currently the State Capital (IKN) of the Republic of Indonesia, has a role as the center of government and the center of the economy. This dual function of authority has caused this area to continue to experience an increase in population. These conditions have not been matched by environmental capabilities and urban planning (Yahya 2018). There are still many problems that have not been resolved, such as floods (Pratiwi \& Rahajoeningroem 2020), urban heat islands (Hamdani 2020) air pollution (Gavrila \& Rusdi 2020), and river water pollution (Rachmawati et al. 2020).

DKI Jakarta has potential hazards related to the sea and climate change, because the city is located in a coastal area where interactions between land and sea land are occurring. In addition, the burden of buildings and infrastructure above the city of Jakarta causes land subsidence (Ramadhanis et al. 2017). As a result, areas that are located close to the sea will be easily affected by flooding. This problem will get worse if there is an increase in sea level. The complexity of the problems in Jakarta caused the government of the Republic of Indonesia to decide to move one of the functions owned by DKI Jakarta, namely as the center of state government (Hasibuan \& Aisa 2020).

It is hoped that the relocation of the National Capital City (IKN) can mobilize residents from Jakarta, so that problems in this city are more easily resolved. Right on Monday, 26 August 2019, the elected President of the Republic of Indonesia (2019-2024) Ir. Joko Widodo officially announced through a press conference that the new location for the IKN was in East Kalimantan Province, to be precise in parts of North Penajam Paser Regency (PPU) and partly in Kutai Kartanegara Regency (Nugroho 2020). After announcing the location of the IKN move, the government began holding competitions related to the IKN city planning design, determining the advisory board, foreign consultants, recruiting special employees to handle the IKN move, and looking for investors.

\footnotetext{
*Corresponding author: abdul.kodir.fis@um.ac.id
} 
The government claims that East Borneo is a location which from a geological point of view is very likely to be used as a place for the construction of a new capital city, because it is not included in the red route of Mount Merapi so there is minimal risk of disaster. In addition, according to a written statement by the Head of BMKG Dwikorita Karnawati that although there is a fault structure and has a record of earthquake activity, in general Borneo Island is still relatively safer than other regions or islands in Indonesia (Kurniadi 2019). Apart from that, economic factors are also a strong reason for the gov-ernment to move the State Capital to East Borneo.

So far, the City of Jakarta still dominates the economic cycle in Indonesia (Toun 2018). Business activities centered on the island of Java, especially in DKI Jakarta, have hampered the growth of new economic centers outside Java. The movement of the capital is expected to increase economic equality in Indonesia and the gap between the islands of Java and outside Java. In several studies, it is stated that relocating the capital city will be able to increase the economy by $0.10 .2 \%$ due to the encouragement of new investment (Hasibuan \& Aisa 2020).

The plan to relocate the National Capital has generated a variety of responses from various circles, from the government, Non-Government Organizations (NGOs), local communities, to indigenous peoples in the East Kalimantan region, especially in the location of the construction of the State Capital, namely in Penajam. Paser Utara (PPU) and Kutai Kartanegara. This paper will discuss the dynamics of the response from these parties.

\section{METHODS}

This research uses qualitative methods which are carried out in two stages. First, conducting interviews with several relevant stakeholders, such as: community leaders, village heads, village officials, customary communities, and several nongovernment organizations (NGOs) who are concerned with environmental issues. Second, through focus group discussions with local communities. This research was conducted in Penajam Paser Utara (PPU) and Kutai Kartanegara Municipality. The process of determining information using purposive sampling technique. There are several requirements in choosing a participants, namely residents in both locations, both indigenous and nonindigenous, village and subdistrict officials, private parties who own companies around the location, NGOs engaged in the environmental sector.

\section{RESULT AND DISCUSSION}

Dynamics of Community Response to the Development of the State Capital (IKN) in East Kalimantan in a Political Ecology Approach

Political ecology sees environmental change as not neutral and in a vacuum but a form of "environmental politics" that involves interested actors at the local, regional and global levels (Bryant $\&$ Bailey 1997). This is where we will see how the power of the political economy can influence environmental change. Raymond L Bryant and Sinead Bailey in their book entitled Third World Political Ecology emphasize that there are several actors involved in ecological political issues, including the state, companies or business groups, Environmental Non-Governmental Organizations (NGO), and society (Herdiansyah 2018; Kodir 2019). The four actors have different interests in relation to the case of the development of the State Capital in East Kalimantan, thus giving rise to different perceptions regarding whether or not it is necessary to move the capital city. This has resulted in various pro and contra opinions in response to the IKN development plan.

These pros and cons can be said to be reasonable considering the relocation of the National Capital City (IKN) requires a lot of consideration from various parties to measure the effectiveness of governance in the new capital. Based on the research results, the perception formed in the public is still dominated by negative sentiments. The threat of environmental degradation that has the potential to arise due to development is the reason for refusing to move the IKN (Salsabila $\&$ Nurwati 2020). In addition, there are also issues of interest from certain groups behind the 
development of the IKN in East Kalimantan (Ilmawan, no date). However, there are also groups who agree with the IKN development. The strong reason behind this is the belief that IKN can create socioeconomic changes for the better, especially for the people of East Kalimantan.

\subsection{Community groups who are pro against the development of the state capital (IKN) in East Kalimantan}

Most of the communities who agree with the development of the IKN in East Kalimantan are those who feel benefited from this project, ranging from local communities themselves, NGOs, investors, to political leaders (Mardhiyah 2020). There are several reasons behind this group agreeing with the development of the IKN in East Kalimantan, among others: first, the land in the area that will be the location for relocating the capital city is in great demand by investors and businesspeople. This is beneficial for local communities who own a large area of land in the area. Land prices experienced a significant increase after East Kalimantan was designated as the location for the new IKN, where per hectare reached a price of 1 billion. In addition, the development of the capital city also requires a large amount of funds. Of course, this is beneficial for investors who will invest in the project.

Second, based on the findings of the East Kalimantan Indonesian Forum for the Environment, there are a number of names from the political elite who support the existence of the IKN (Hutasoit 2019), because they have the potential to benefit from the megaproject. These politicians have extractive industry concessions, namely mining, coal, palm oil, timber, coalfired power plants and giantscale hydropower plants, as well as property entrepreneurs (Nahak 2019). The IKN project is used as a means of whitening the company's sins for environmental destruction due to their activities. This condition is called by Doris Capistrano and Carol J. Pierce Colfer (2006) as elite capture, or the ability of those who have power and wealth to take advantage of new opportunities and increase their power/authority and wealth.

Third, East Kalimantan is considered to be an island that is relatively safe from earthquakes (technical and volcanic) because it is not crossed by faults in the earth's crust and does not have a series of active volcanoes (Kurniadi 2019), so it deserves to be recommended as a candidate for the capital city. Fourth, the proIKN movement groups think that spatially Jakarta is too densely populated, as the center of government, tourism, industry, poor spatial planning, and there are many contradictory land uses. In contrast to the island of Kalimantan, which has quite extensive land availability (Pandit 2019), so that it can compile an ideal capital city layout.

Fifth, the proIKN movement groups also reasoned that by moving the local women it would shift the epicenter of national development from Java to outside Java. This is considered as a strategy for equitable development. So far, economic development has been centered on the island of Java, especially in Jakarta, while people in Kalimantan are still living in limitations. People living in the border area of Kalimantan Malaysia actually have easier access to their basic needs from this neighboring country than from Indonesia, because of the further distance to cities in Indonesia and difficult access to them. The island of Kalimantan is also an area located in the middle of Indonesia, so the proIKN movement groups believe that economic equality will be more easily realized.

\subsection{Community groups who counter the development of the national capital city (IKN) in East Kalimantan}

Various rejection reactions have also colored the plan to build the State Capital (IKN) in East Kalimantan. In general, the actors who oppose the existence of the IKN development are indigenous peoples, local communities, and NGOs engaged in the environmental sector in East Kalimantan, such as the Indonesian Forum for the Environment (Walhi), Jarangan Mining Advocacy (Jatam) East Kalimantan, Working Group (Pokja 30), Coastal and Fishermen Working Groups, and the Balikpapan Bay Care Forum (FPTB). 
The main issue that concerns the contra group is the land problem in Sepaku District, North Penajam Paser Regency (PPU), the location where the capital will be built (Safra \& Zuliarso 2020). There are still several villages and subdistricts whose land management systems use customary law or an inheritance system so that they do not have legality over the land, one of which is in Pemaluan village. For people in this village, land is something sacred, as stated by Abiodun Alao (2007) that land is one of the natural resources that must be preserved for future generations. However, this subdistrict is located in Ring 1 of the IKN or the area closest to the development site, causing anxiety for indigenous peoples if their land is taken over by the state without clear compensation because there is no legality.

The community's rejection of the IKN development is not only because of their respect for the environment, but more on their dependence on the environment in which they live. The same thing was said by Raymond L. Bryant that the life of rural communities has a very strong attachment to the environment in which they live. If there are policies that disturb the stability of their place of life, the grassroots actors will defend their environment (ROBBINS 2005).

Another problem that causes people to reject the presence of IKN in East Kalimantan is that the government does not involve them in planning the IKN (Sujana 2019), so that people feel marginalized from their own place of life. This marginalization is perceived by the community as a form of injustice, so that those who feel pressured take up resistance. So far the community has made efforts to meet between traditional institutions in Penajam Paser Utara (PPU) to discuss these issues. However, the customary institutions that attended this meeting were only formal institutions made by the regional government located in the PPU Regency, while the traditional leaders in rural areas were not involved. Even though it is the customary head who better understands the complexity of the problems in their customary territory.

Another reason that causes rejection is that the construction of the IKN will only duplicate the existing problems in Jakarta to East Kalimantan. Based on several studies conducted by NGOs in East Kalimantan, it was found that behind the IKN project there were the oligarchs' dirty business. These findings state that the IKN development is only a mega (sharing) project after the 2019 presidential election. This can be seen from the political supporters of the elected president in 2019-2024, who have a background in coal business in East Kalimantan. The need for coal energy for the needs of the IKN itself is estimated at $1.5 \mathrm{GW}$ (Nugroho 2020), this of course will be a reason to build an even bigger Coal Power Plant industry in East Kalimantan. This industry will certainly have a negative impact on the environment on the island of Kalimantan, as well as the environmental problems currently facing Jakarta.

\section{CONCLUSION}

The plan to relocate the State Capital from Jakarta to East Kalimantan still requires a more indepth and comprehensive scientific study so as not to produce rash decisions that will result in the stability of the administration of the state. In general, it can be concluded that the public response to IKN development is still dominated by negative sentiment. This can be seen from the rejection of several parties who do not support the presence of IKN in East Kalimantan. There are various reasons behind this rejection, including: 1) there is no clear protection of the ownership of land belonging to indigenous peoples around the development site, so this project only gives people a sense of worry if their land is taken over by them. 2) The IKN development plan has not involved the local community in making policies. 3) There is an assumption that moving the capital city is the same as moving problems in the old capital to East Kalimantan. Despite the objections, some people also agree with the development of the State Capital in East Kalimantan. The most common reason is the desire for socioeconomic changes for the better for the people of East Kalimantan after the island officially becomes the capital. Besides the pros and cons of the IKN development, there are also those who respond to the IKN neutrally. 


\section{REFERENCES}

Bryant, R. L. and Bailey, S. (1997) Third world political ecology. Psychology Press.

Gavrila, N. and Rusdi, F. (2020) 'Analisis Framing Detik. com dan Kompas. com Terhadap Pemberitaan Kualitas Udara Jakarta Terburuk di Dunia', Koneksi, 3(2), pp. 366-371.

Hamdani, R. S. (2020) 'Proyek Lintas Batas Administrasi: Analisis Partisipasi Publik dalam Proses Perencanaan Ibu Kota Negara Republik Indonesia', Journal of Regional and Rural Development Planning (Jurnal Perencanaan Pembangunan Wilayah Dan Perdesaan), 4(1), pp. 43-62.

Hasibuan, R. R. A. and Aisa, S. (2020) 'DAMPAK DAN RESIKO PERPINDAHAN IBU KOTA TERHADAP EKONOMI DI INDONESIA’, AT-TAWASSUTH: Jurnal Ekonomi Islam, 5(1), pp. 183-203.

Herdiansyah, H. (2018) 'Pengelolaan Konflik Sumber Daya Alam Terbarukan di Perbatasan dalam Pendekatan Ekologi Politik', Jurnal Hubungan Internasional, 7(2), pp. 144-151.

Hutasoit, W. L. (2019) 'Analisa Pemindahan Ibukota Negara', Dedikasi, 39(2), pp. 108-128.

Ilmawan, M. I. (no date) 'Analisis Isi Pemberitaan Pemindahan Ibu Kota Negara Republik Indonesia di Portal Berita Online Detik. com dan Republika. co. id'. Fakultas Ilmu Dakwah dan Ilmu Komunikasi Universitas Islam Negeri Syarif ....

Kodir, A. (2019) 'Political Ecology of a Spring', Journal of asian sociology, 48(2), pp. 179-198.

Kurniadi, A. (2019) 'Pemilihan Ibukota Negara Republik Indonesia Baru Berdasarkan Tingkat Kebencanaan', Jurnal Manajemen Bencana (JMB), 5(2).

Mardhiyah, T. A. (2020) 'WACANA PEMINDAHAN IBU KOTA DI MEDIA SOSIAL (Analisis Wacana Kritis Model Teun A. Van Dijk Pada Youtube Kumparan) SKRIPSI'. IAIN.

Nahak, S. (2019) 'Implikasi Hukum Pertanahan Terhadap Pemindahan Ibu Kota Negara Republik Indonesia Dari Jakarta Ke Kalimantan Timur', Ganaya: Jurnal Ilmu Sosial Dan Humaniora, 2(2-2), pp. 31-40.

Nugroho, H. (2020) 'Pemindahan Ibu Kota Baru Negara Kesatuan Republik Indonesia ke Kalimantan Timur: Strategi Pemenuhan Kebutuhan dan Konsumsi Energi’, Bappenas Working Papers, 3(1), pp. 33-41.

Pandit, I. G. S. (2019) 'Dampak Pengelolaan Lingkungan Hidup Bagi Kalimantan Timur Sebagai Ibu Kota Negara Serta Penyelesaian Sengketa Hukumnya', Ganaya: Jurnal Ilmu Sosial Dan Humaniora, 2(2-2), pp. 15-21.

Pratiwi, V. and Rahajoeningroem, T. (2020) 'Perencanaan Prasarana Dan Sarana Sistem Pengendalian Banjir Kota Administrasi Jakarta Pusat', Indonesian Community Service and Empowerment (IComSE), 1(1), pp. 36-44.

Rachmawati, I. pramudita, Riani, E. and Riyadi, A. (2020) 'Status Mutu Air Dan Beban Pencemar Sungai Krukut, Dki Jakarta', Jurnal Pengelolaan Sumberdaya Alam dan Lingkungan (Journal of Natural Resources and Environmental Management), 10(2), pp. 220-233. doi: 10.29244/jps1.10.2.220-233.

Ramadhanis, Z., Prasetyo, Y. and Yuwono, B. D. (2017) 'Analisis korelasi spasial dampak penurunan muka tanah terhadap banjir di jakarta utara', Jurnal Geodesi Undip, 6(3), pp. 77-86.

ROBBINS, P. (2005) 'Political Ecology Oxford: Blackwell Publishing, 2004, 242 p. ISBN 140510265 9', Doc. Anàl. Geogr, 45, p. 181.

Safra, I. A. and Zuliarso, E. (2020) 'ANALISA SENTIMEN PERSEPSI MASYARAKAT TERHADAP PEMINDAHAN IBUKOTA BARU DI KALIMANTAN TIMUR PADA MEDIA SOSIAL TWITTER'.

Salsabila, A. H. and Nurwati, N. (2020) 'DEFORESTASI DAN MIGRASI PENDUDUK KE IBU KOTA BARU KALIMANTAN TIMUR: PERAN SINERGIS PEMERINTAH DAN MASYARAKAT’, Prosiding Penelitian dan Pengabdian kepada Masyarakat, 7(1), pp. 27-39.

Sujana, I. N. (2019) 'Penguatan Hak Penguasaan Tanah Adat Masyarakat Hukum Adat di Kalimantan Timur sebagai Rencana Ibu Kota Negara’, Ganaya: Jurnal Ilmu Sosial Dan Humaniora, 2(2-2), pp. 49-57.

Toun, N. R. (2018) 'Analisis Kesiapan Pemerintah Provinsi Kalimantan Tengah dalam Wacana Pemindahan Ibu Kota Negara Republik Indonesia ke Kota Palangkaraya', Jurnal Academia Praja, 1(01), pp. 129-148.

Yahya, M. (2018) 'Pemindahan Ibu Kota Negara Maju dan Sejahtera', Jurnal Studi Agama dan Masyarakat, 14(1), pp. 21-30. 